\title{
Role of the River Danube in the Spatial Development of Central- and South-East Europe
}

\author{
Péter Kovács ${ }^{\mathrm{A}}$ \\ Received: March 2011 | Revised: May 2011 | Accepted: June 2011
}

\begin{abstract}
In this article the author tries to answer the question if the river Danube - as a natural element - has an authentic role in the formation and shaping of the geographical space in its basin. Except the centuries after the foundation of the Hungarian Kingdom, the development of the region was influenced by external powers: Rome, Byzantium, Moscow and the German sphere of interests. The effects are manifested in many fields of life ranging from culture, to economy, trade and geopolitics. If the expansion of the powers was perpendicular to the Danube [by Rome and Moscow], the border character was strengthened; if it was parallel, then the corridor character came to the front. As a result it is visible that the role of the Danube in the evolution of spatial structures was not highly relevant, but rather regional and temporal until today.
\end{abstract}

Keywords: external powers, border character, corridor character

\section{Introduction}

The Danube region is on of the most interesting and controversial areas of Europe in geographical and historical viewpoint, moreover; due to the Danube Strategy it is especially suitable to deal with topical issues as well. Positioning of the region on the political geographic map of the continent is quite difficult, since - as Zoltán Hajdú described in his Balkan related paper in 2002 (Hajdú, 2002 ) - this is rather an "according to area", the external border and internal structure, organization of which is quite plastic and not well-clarified. The Danube-basin can rather be comprehended as a kind of perceptual, conceptional region (Trócsányi, 20Io) of Europe that is culturally, politically, economically, and ethnographically heterogeneous and hard to impound.

Several historians and politicians dealt already at the turn of the century with the role of the Danube region in the European geopolitics, respectively with the reformeability of the Austrian-Hungarian Monarchy. Maybe one of the most appreciable among them was Oszkár Jászi, who - though he profoundly knew the ethnic circumstances - did believe in the cooperation of the nations along the Danube and in the permanent survival of a Danube state (Jászi,I9I8; Jászi, I986). Even recently nu- merous editions and studies were published on the spatial organization of Central-Europe (Németh, 200I), on the power-political circumstances of the region at the turn of the century (Németh, 2009); or on the Danube-related integration and disintegration plans (Romsics, 1997) and policy (Radics, I946; Wierer, I960; Gorove, I964; Ormos, I969; Kosáry, I990; Romsics, 2005) of great powers of Europe, which clearly shows that the topic is unclosed even today.

Next to history, numerous excellent representatives of geography deal/dealt with the processes taking place in the Danube-basin, mainly from spatial viewpoint. Geography regarded Danube as an axis, a corridor that connects the nations of Central- and Southeast-Europe. This axis function was investigated from different aspects. Some regarded it as a transportation and trade corridor (Erdősi, 2002, Erdősi, 2008), others interpreted it as a direction of innovation diffusion (Rechnitzer, 2002); but studies has been published also on its effect on the historical-geographical spatial development of the region (Gál, 2003).

The question may arise why further investigation of the geopolitical aspects is interesting for us. In my reading the extra-regional geopolitical

A Doctoral School for Earth Sciences, University of Pécs, Hungary; e-mail: koko@boly.hu 
centres (Roman, German, Turkish, Russian) always have exerted a significant impact, they provided a kind of example for the Danube states on social arrangement, and cultural identity. In addition, they significantly influenced the direction and intensity of - primarily external - economic and trade relation networks. Since such multidirectional influences exerted an impact/ effect on the region, the question arises whether the Danube-basin can be comprehended as a region of Europe that has several autonomous power centre(s) or is it solely the playing field of great powers that extends or totally disappears depending on their strength. Has the river as a physical geographical element indeed played any spatial shaping, space-keeping role in the development and evolution of the region's states or is it merely an illusion that is created in the observer by the simple existence, physical connecting role of the stream?

\section{Results and Discussion}

\section{Importance of the river Danube in the last centuries of the antiquity}

By investigating these issues it is worth looking back at around the beginning of the historical times, when the Roman Empire - led by Principatus Augustus - established the provinces (Pannonia, Moesia) along the middle- and down-stream of the Danube, that were bordered by the Danube on east and north. This was the first occasion that a single external centre of power was able to extend its sphere of interest along the whole stream (Figure I). This was not only a military, but also an economic and cultural influence that appeared in the foundation of cities, in the building of the road network, in the administration and in many other spheres of the everyday life. This power ex-

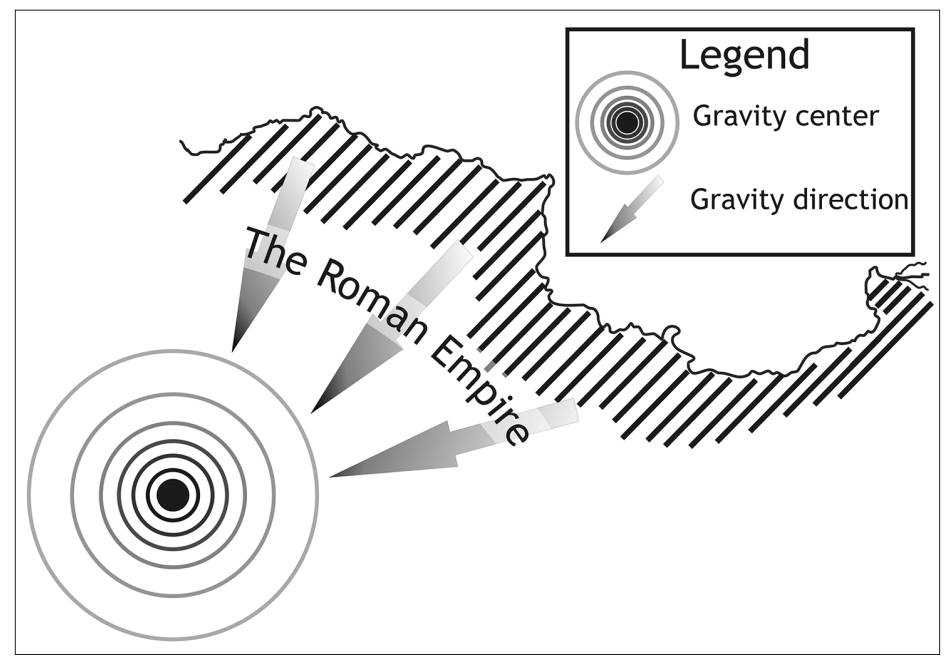

Figure 1. Gravity centre of the Danube region in the antiquity tended only on the right bank of the Danube - except the era when Dacia province existed -, since the river itself - as a barrier that is wide and difficult to cross, as a real space shaping force - functioned as a natural border, as a part of the strategic protection system of the Empire. The organization of the territory can be seen as one-sided, even though we have some information about bridgeheads, maybe settlements on the left bank as well, and the border created by the limes - also called a ripa Pannonica, giving a hint on the stream character of the border - did not impede peaceful interactions.

\section{Transformation of the spatial structure, appearance and rise of the Hungarian Kingdom}

The tribe incursions that invigorated since the middle of the fourth century led to the weakening, and later, by the last third of the fifth century, to the fall of the empire. For nearly one and a half millennia since that time on, neither an internal, nor an external great power was able to extend his sphere of interest along the whole stream of the river. The fall of Rome fundamentally altered the macro structure of political sphere in Europe. Constantinople remained - though often with an Asian centre of gravity - far the most important centre of power on the east side of the continent, while the western territories of Europe were subordinate by the Frankish Empire that was loosely organized at the beginning, but centralized and spatially extended under Charles the Big. For a short period the Avars settled down in the Middle-Danube-basin, they were followed by the Frankish. During this period the First Bulgarian State was created in the Lower Danube area, which, though it had a middle-power status, was culturally evidently related to Byzantium (Szeberényi, 2007). A - from the antiquity fundamentally different - multipole power structure came into existence along the river (Figure 2) with the Hungarian Kingdom that was consolidated in the Carpathian-basin around the turn of the millennium. Besides the external geopolitical centres, an internal, autonomously organized centre of power appeared, which dominated the Middle-Danube-basin for a long time, but it was never able to extend his power on the whole territory. During this period the Danube functioned as a very important cultural corridor, e.g. Christianity, states, urbanisation, administrative system etc.

Consequently, the period between rooo and I300 was mainly characterized by the existence of a few centres of power that stood in connection, but did not violate the sphere of interest of each other: with Bavaria in the upper stream and later on more and more evidently also in the 
territory of the present Austria, with the Hungarian Kingdom in the middle, on the south-east basically with the Bulgarian, later on somewhat with the Serbian state formations. Among these actors, the rise and consolidation of the Hungarian State is due to the fact that it took place in the dead ground of sphere of influences, at an "amphidromic point" of two external centres of power (the German-Roman Empire and Byzantium) that have a significant influence on the Danuberegion. However, hence in this era the two external powers moved along opposite paths (the influence of Byzantium was decreasing, while the cultural affect of the German-Roman Empire was increasing even against its political disorders), the balance of power was dissolved and the western orientation of the Hungarian Kingdom became unquestioned. For a short period of time, this shift also enabled the extension of the influence of the Hungarian State towards south-east along the river.

The transformation of the geopolitical structure was guided by the change of the river's role as a physical geographical formation. As some states occupied both banks of the river, its border function disappeared and its role as an axis, a corridor, a channel of innovation gained on importance.

\section{The role of the river in the era of the Turkish conquest}

The structure evolved by the time of the millennium stayed surprisingly stable for three-four centuries. Significant transformations occurred when the conditions and social demand of expansion became established in both external great powers, and this coincided in time with the accumulation of the internal structural problems of the Hungarian Kingdom that was located in the middle.

The signs of the transformation became first apparent in the Balkan: on the ruins of the unstoppable dying Byzantium a new state of the Ottoman Turks settled that reached the Danube-ba$\sin$ at several locations due to its rapid expansion, assimilating the former Bulgarian and Serbian territories, even though Hungary fought eagerly to protect the remains of these (Barbarics-Hermanik, 2007). In the $\mathrm{I}^{\text {th }}$ century the core territory of the latter, the Carpathian-basin had became battlefield - in 154I the Ottomans conquested Buda and the Kingdom of Hungary fall into three parts -and the middle empire that earlier had been significantly influenced the destiny of the area, practically dissolved. The Danube played a more important role in the process than ever before: the supply of the Ottoman army that grew extremely large compared to the logistical conditions of the era, could have hardly been solved

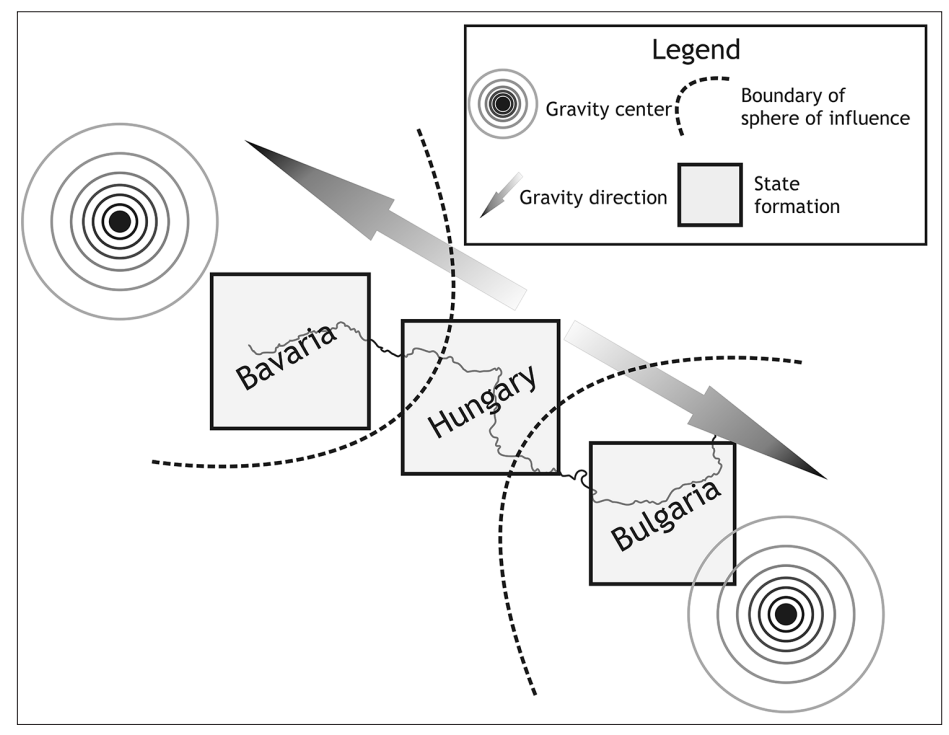

Figure 2. Division of the Danube Region between the foundation of the Hungarian Kingdom and 1541

without shipping in such a distance from the operation base. It is not accidental that the fiercest sieges of the Hungarian battlefield were directly related to the occupancy of the fortresses that controlled shipping (Buda, Esztergom, and Györ). The reason of the balking of Turkish expansion lies, next to the doubtless impacting geographical factors (action radius theory), in the rise of another centre of power.

Basically simultaneously with this, among the coulisses of the slowly crumbling state of the German-Roman Empire, arose the Habsburgdynasty that anchored its dominion of the Austrian regions that meant a solid base along the upper stream of the river. Though for a long time it seemed that the conglomeration dominated by

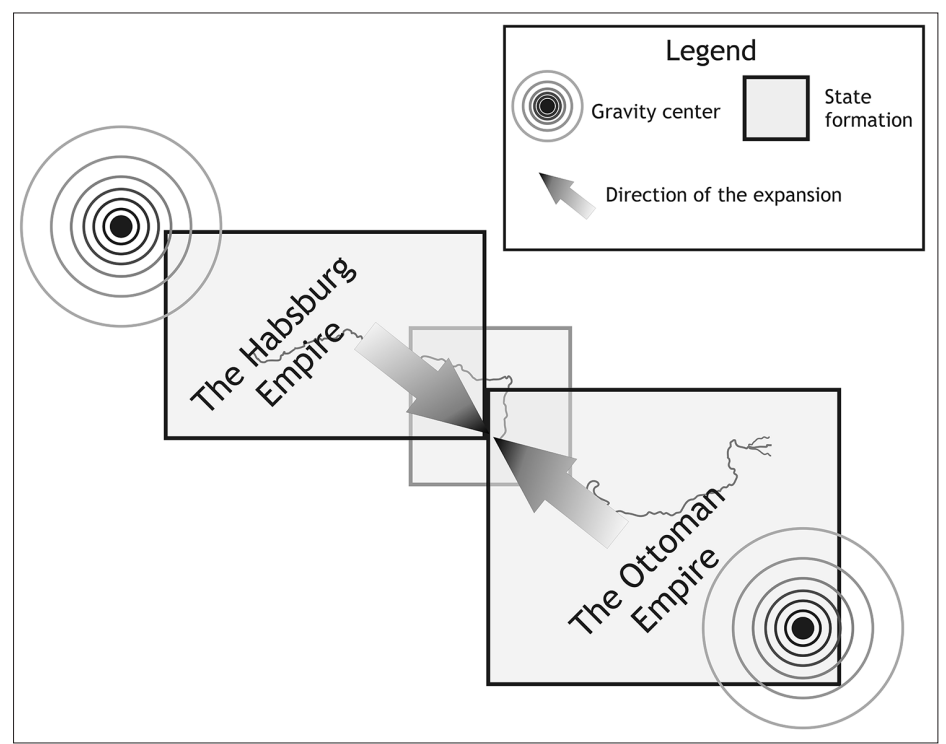

Figure 3. Geopolitical division of the Danube region during the Ottoman Hungary period 
the successfully marrying dynasty can be consolidated on German, later on Spanish base, the history turned out to be different. Exactly the fall of Mohács and that of the Hungarian State, respectively gathering of the Jagellonian-heritage led to the fact that the centre of gravity of the divided Habsburg state-conglomeration became positioned in the Danube-basin. All the same, their relations with the European centre became more intense, and while it fought long with the Ottomans for the occupancy of the middle-basin, it significantly increased the western integration of its assimilated territories. Even as the eastward expansion of the Habsburgs, the Ottomans used the Danube valley as a natural military route too. Therefore the Danube served not only a corridor of culture, but also a corridor of political and military sense. (Figure 3).

\section{Change of the geopolitical structure from the Habsburg occupancy until the end of the World War II}

At the end of the $17^{\text {th }}$ century, the Habsburgs not only broke the Turkish dominance in the MiddleDanube-basin, but at the same, they filled in the power gap that the Hungarian Kingdom was unable to do. The corridor character of the stream continued to function in the described era.

This was the first time that a centre of power by European standard represented by Vienna was located into the Danube-basin, even though the real economic and leading cultural centre of the continent was far more west from there. This centre had an active political, cultural and economic expansion towards - as an only possible direction - east. This can be traced most obviously in the settlement of the so called "Danube Krauts", in the linguistic Germanization efforts or even in

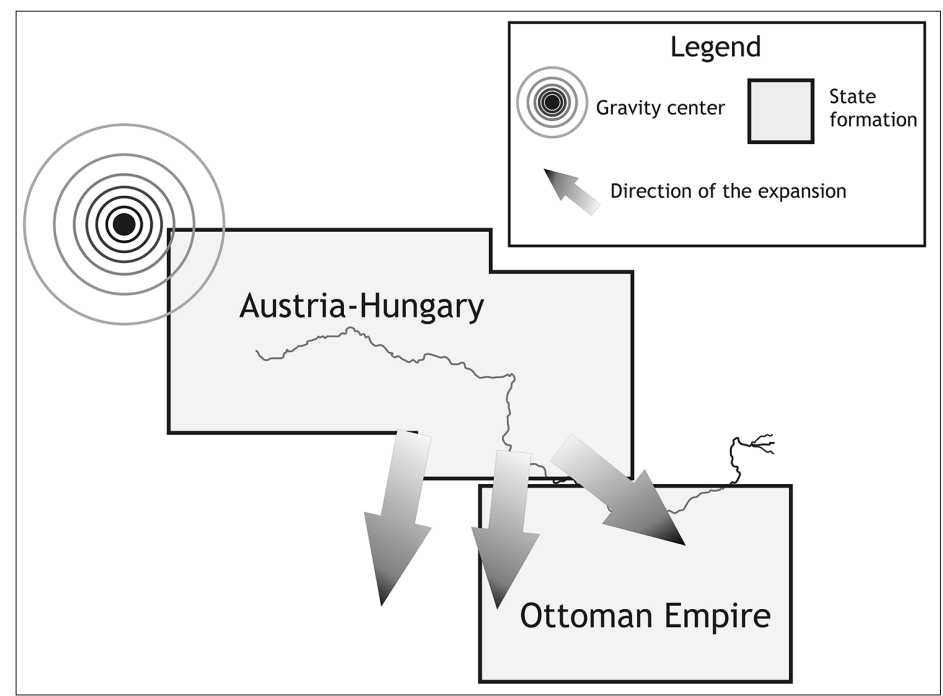

Figure 4. Geopolitical division of the Danube region between the $18^{\text {th }}$ century and 1914 the formation of the economic area protected by double customs. The establishment of the Austrian-Hungarian Monarchy in 1867 made the already obvious fact also on the state level explicit that a great power was founded in Central-Europe that relied on the Danube-axis, was autonomous within the region, but followed Western European cultural patterns and was based/relied on the renewed and by the Hungarian empire-side extended power-base of the dynasty that had lost its European (in chronological order: Netherlander, Italian and German) concernments. Though it was not able to territorially expand his power on the whole basin, it successfully represented through its economic influence the all-time cultural interests of the imperial court along the whole river Danube. This expansion was permanent until World War I, though volatile in its intensity, actually it reached its peak during the war years (Figure 4).

The issues of territorial re-structuring following World War I divided the European great powers. It was obvious that the consolidation of Germany had to be impeded by all means. However, opinions related to the Austrian-Hungarian Monarchy were not unique. France argued next to splitting and the possible strictest territorial revisions; on the contrary, Great-Britain put an emphasis on the reasonable, ethnicity-based spatial division and also highlighted the safekeeping of the region's economic unity. In this era of very ductile international relationships, the previous expansion broke, and later on clearly interrupted.

By the 1930 Germany became one of the leading powers of Europe again, both in economic and political sense. One of the expansion directions of the Third Empire remained the river. The small states of the Danube-valley meant very important energy, raw material and food base of the German wartime economy. Since Germany compensated the products of these countries at a higher price than the world average and gave industrial equipment in turn, it pushed the Central-European states into strong economic and consequently political dependency (Berend T., Ránky, I976). As a result, the western centre of power - in this case Hitler's Germany - expanded his geopolitical sphere of influence again on the whole Danube-valley by making use of its traditional cultural and economic political relationships - that was completed in military sense by an extremely rapid invasion at the spring of I94I. In the author's view this process is nothing else than the continuing, temporal fulfilment of the previously/earlier already experienced south-eastern expansion, that also had a German cultural background, on a more solid power base and with more effective tools. 


\section{Decades of the dictatorship}

Due to the implosion of their economies, the great powers of West-Europe - e.g. France and GreatBritain - could only partially fill the power vacuum created by the end of World War II and by the collapse of Germany. On the contrary, the eastern centre of power - the Soviet Union - finished the war with victory, additionally it became economically and politically stronger, hence, it was a reasonable claim to extend its sphere of influence on the eastern part of Europe, almost hermetically restricting the region from West-Europe with the creation of the iron curtain (Kennedy, 1992). (Figure 5)

With its expansion activity that was perpendicular to the region, the centre of power represented by Moscow practically reinforced the border character of the Danube again. Though the river itself did not mean a physical border, as it had functioned in the antiquity, but the geopolitical, economic and cultural division line that resulted in the unique from the West-European different - development of the Middle- and Lower-Danube-basin for decades, laid in within the region. Repeating of the previous examples is indicated by the fact that while at the turn of the millennium the Hungarian Kingdom could gain on strength in the shadow of the two mutually extinguishing power fields, now Tito's Yugoslavia shows similar features.

\section{The period after the transition of $1989 / 90$}

The economic and ideological system represented and created by the Soviet Union was broken by the end of the I980s and at the beginning of the I99os the countries of the region turned away form the Eastern Block and adopted western orientation. By that time, the countries of West-Europe agglomerated to a worldwide strong economic and partially political unit due to their cooperation, the most important state of which was again - and with time more and more openly - Germany. The western centre of power - that is in Europe best characterized with the Union and the NATO - was eager to fill the power gap left behind by the shrinking of the Russian influence. One of the first steps was the accession of Austria to the European Union in 1995. This process was continued with the NATO accession of Hungary, Poland and Czech Republic and with the - Danube-valley directed - enlargement of the union in 2004 and 2007 - the western centre of power extended its influence almost on the whole region again. At the end it closed the fight that started with the fall of the Roman Empire for the occupancy of the whole Danube-valley - there may be rearguard actions related to Serbia - and at the same time, the division, buffer zone character of the river was pushed into the background and its

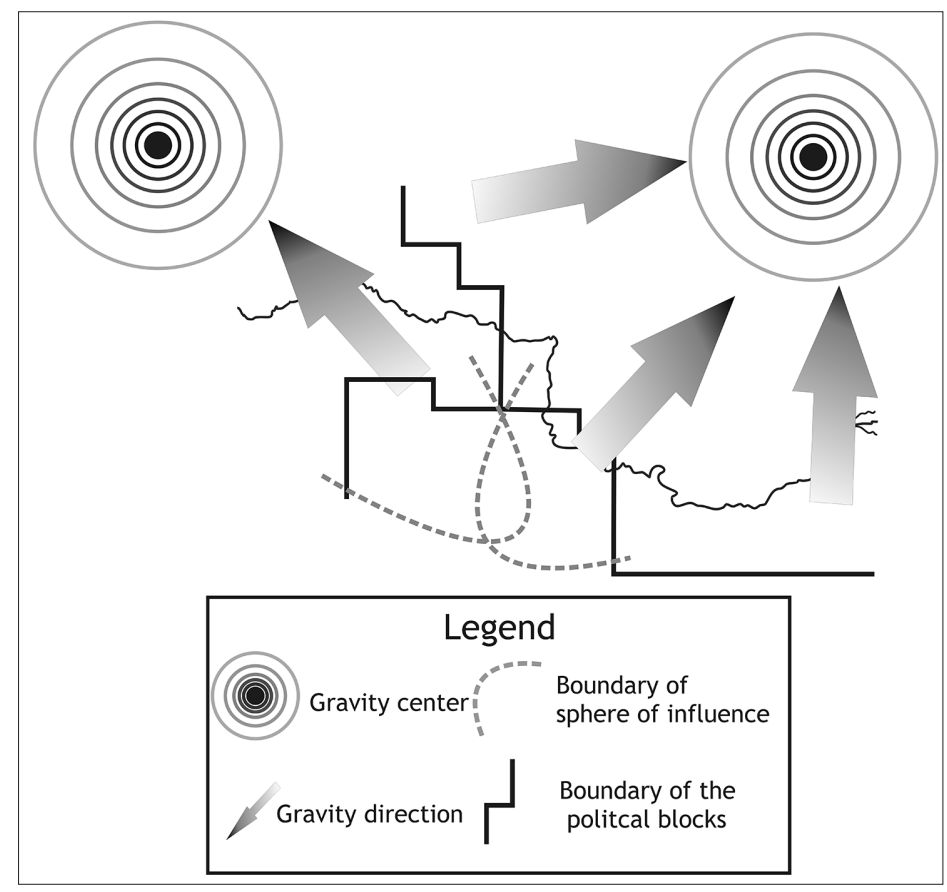

Figure 5. Geopolitical division of the Danube region between 1950 and 1990

corridor effect became strengthened. Whether it is a kind of end situation or only a stage in the intricate fate of the Danube-bank's nations: everybody should decide how much they believe in the "end of history".

Today, in the framework of the Danube Strategy Germany intends to strengthen its economical and particularly political position in the region. Trough this strategy it tries to strengthen the connecting and space shaping force of the river.

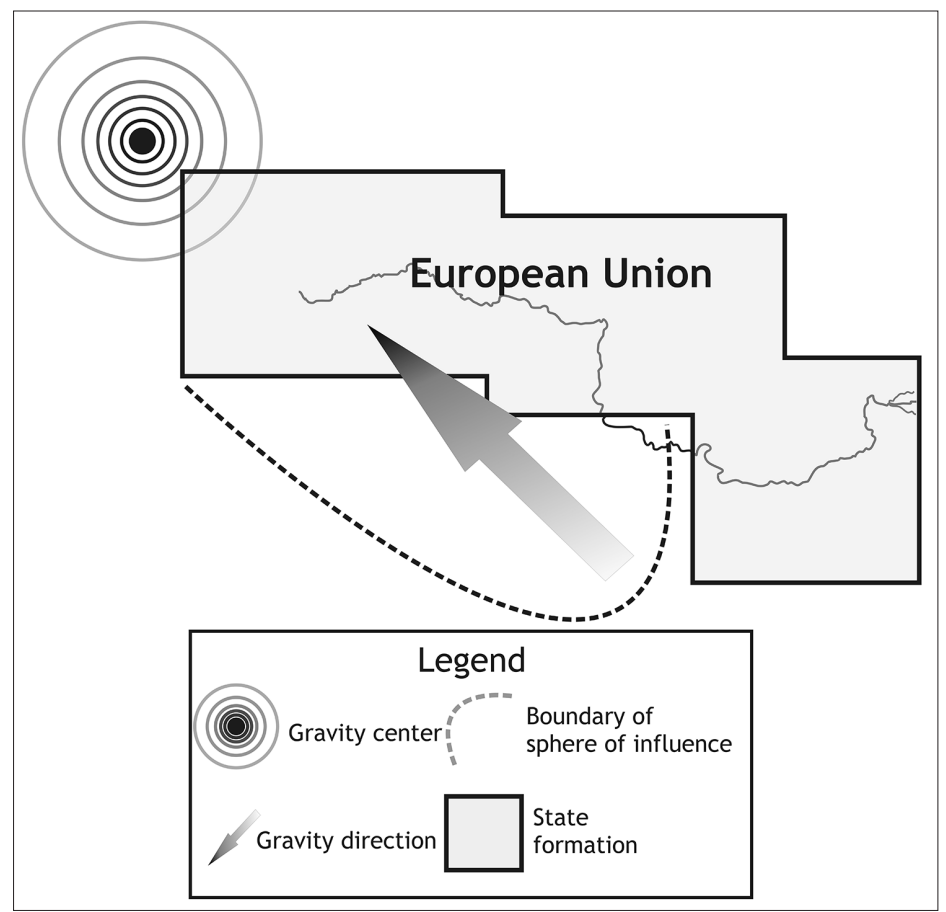

Figure 6. Present geopolitical division of the Danube region 


\section{Summary}

The Danube-basin went through a unique developmental path in the more than one and a half millennia since the antiquity. Except the centuries between the establishment of the Hungarian Kingdom and the Turkish thraldom, the external centres of power: Rome, Byzantium, Moscow or the German sphere of influence have considered this area as one of the most important regions of their empires' extension. Intraregional middle or great powers were not, or only partially were able to extend their influence on the whole Danubebasin. When the great powers had an expansion activity perpendicular to the region - as it was the case with Rome and Moscow -, then it led to the reinforcement of the border function, that of the buffer zone role. On the contrary, if direction of the expansion of great powers was parallel to the river - as in case of the Byzantium and that of the western power centre -, rather the corridor character of the river became dominant that was reflected in the field of culture, innovation, economic relations and that of trade. Summarily we can conclude that the role of the Danube in the evolution of the spatial structure is not dominant, it only becomes strong in certain eras and regionally.

\section{References}

Berend I.T., Ránky Gy. (eds.) I976. Közép-Kelet Európa gazdasági fejlődése a I9-20. században. Közigazgatási és Jogi Kiadó, Budapest, pp I5524I, pp. 377-400.

Barbarics-Hermanik Zs. 2007. Az Oszmán birodalom a Balkánon és Közép-Kelet Európában, I389-I80o. In: Sashalmi E. (eds.) „Kelet-Európa” és a „Balkán” Iooo-180o. Pécsi Tudományegyetem Kelet-Európa és Balkán Története Kutatási Központ, Pécs, pp. 33I-393.

Erdősi F. 2002. A Duna, mint történetileg változó tengely, illetve folyosó. In: Dövényi Z. - Hajdú Z. (eds.): A magyarországi Duna-völgy területfejlesztési kérdései Il. kötet. Magyar Tudományos Akadémia, Budapest, pp. 3I-53.

Erdősi F. 2008. Kelet-Európa országainak vízi közlekedés. MTA Regionális Kutatások Központja, Pécs, pp. 70-I45.

Gál, Z. 2003. Bruchlienien in der Region Donautal: die Rolle der Donau in der mittel- südosteuropäischen historischen - und Raumentwicklung. In: Huszár, Z. - Vándor, A. - Walterné
Müller, J. (eds.): 2000 Jahre entlang an der Donau. Direktion der Museen des Komitates Baranya, Pécs, pp. 295-324.

Gorove S. 1964. Law and Politics of the Danube. Martinus Nijhoff, The Hague, pp. I-52.

Hajdú Z. 2002. A Balkán-félsziget politikai földrajza. In: Pap N. - Tóth J. (eds.) Európa politikai földrajza. Alexandra Kiadó, Pécs, pp. I85-224.

Jászi O. I988. A Monarchia jövője. ÁKV-MEACENAS, Budapest, $133 \mathrm{p}$.

Jászi O. I986. A nemzeti államok kialakulása és a nemzetiség kérdése. Válogatás. Bevezette, válogatta és jegyzetekkel ellátta: Litván Gy. Gondolat Kiadó, Budapest, pp. 74-90.

Kennedy, P. I987. The rise and fall of the Great Powers. Random House, New York, pp. 30-69, pp 186-206.

Kosáry D. I990. Az európai kis államok fejlődési típusai. Akadémiai Kiadó, Budapest, II3 p.

Németh. I. 200I. Európa Tervek, ELTE Eötvös Kiadó, Budapest, pp. I8I-323.

Németh. I. 2009. Hatalmi politika Közép-Európában. L'Harmattan Kiadó, Budapest, 360 p.

Ormos M. 1969. Franciaország és a keleti biztonság: 193I-I936. Akadémiai Kiadó, Budapest, pp. II-I44, pp. 235-25I, pp. 377-400.

Rechnitzer J. 2002. A Bécs - Pozsony - Győr - Budapest innovációs tengely és a magyar területfejlesztési koncepciók. In: Dövényi Z. - Hajdú Z. (eds.): A magyarországi Duna-völgy területfejlesztési kérdései II. kötet, Magyar Tudományos Akadémia, Budapest, pp. II9-I38.

Radics E. 1946. A Dunatáj Ill. kötet. Gergely R. R. T. kiadása, Budapest, 626 p.

Romsics 1. 1997. Expanzionizmus és regionalizmus. Integrációs tervek Közép- és Kelet-Európáról a I9. században és a 20. század elején. In: Romsics I. (eds.): Integrációs törekvések Középés Kelet-Európában a I9. és a 20. században. Teleki László Alapítvány, Budapest, pp. 7-6I.

Romsics I. 2005. Helyünk és sorsunk a Duna-medencében. Osiris Kiadó, Budapest, 378 p.

Szeberényi G. 2007. A Balkán, 800-I389. In: Sashalmi E. (eds.) „Kelet-Európa” és a „Balkán” Iooo-I80o. Pécsi Tudományegyetem Kelet-Európa és Balkán Története Kutatási Központ, Pécs, pp. 279-330.

Trócsányi A. 20I0. A kulturgeográfia alapjai. In: Tóth J. (eds.): Világföldrajz. Akadémia Kiadó, Budapest, pp. 619-645.

Wierer, R. I960. Der Föderalismus in Donauraum. Forschungsinstitut für den Donauraum, Wien, $236 \mathrm{p}$. 